$$
\text { FOOD AND THE CHILD. }
$$

TWO conferences held in London since our last issue show that increasing attention is being given to questions relating to the physical and mental development of children from a national point of view. At one conference, held at the Guildhall, the subjects considered related to diet at public and private secondary schools; and at the other, held at the University of London, the health of the child in relation to its mental and physical development formed the general basis of discussion.

Of all that mankind has attempted since the world began, there is nothing which it has practised so regularly, so persistently, and on the whole so successfully as eating and drinking. It is therefore somewhat disquieting to find the great civilised nations suddenly smitten with misgivings as to whether the rising generation is being suitably nourished. It is admitted that the provender provided for the betterclass school children of to-day is more abundant in quantity, better in quality, and better served than that supplied to their immediate ancestors; that it is, indeed, exceptional for the fare to be actually deficient in amount, while, whatever its form, it certainly comprises those essential elements of proteids, fats, and carbohydrates upon which previous generations achieved a national pre-eminence. Yet, evidence accumulates to the effect that all is not well with the school child in relation to his diet; and, this being so, the impression arises that the fault lies with the eater at least as much as with the food supplied to him. This also appeared to be the opinion of most of those who spoke with authority and from experience at the recent conference on school diets.

The healthy normal child will eat with avidity of plain wholesome fare, and may even be trusted to eat of it to repletion without risk of injury, it was stated. But, by the healthy normal child was clearly meant one whose teeth were sound, who used them effectively for complete mastication, and whose natural appetite had not been vitiated by a too promiscuous feeding on more highly seasoned viands at home. Now only a small proportion of school children possess quite sound teeth. The rest have mouths more or less septic, and, consequently, infected digestive tracts. Practically none masticate their food completely, and their digestion is by so much the further hampered; while many of those belonging to the upper social classes, when at home, share the more delicately prepared and attractively flavoured foods which are needed to stimulate the faded appetites of their parents, and consequently come to regard simpler fare as insipid and unappetising.

The situation is one of national importance. It calls for a reform of the home dietary and upbringing -beginning in the earliest nursery days-quite as much as for a reform of school diets. The latter may, indeed. be here and there modified with advantage, both in matter and in method; these details, important enough in themselves, were more or less clearly hinted at, but a single-day conference did not provide the time for their adequate consideration. The conference, so far as it went, was as a useful and most suggestive troubling of the waters. Its repetition on a more complete and more comprehensive scale would serve to bring out with greater clearness the need for some effective collaboration between the home and the school in relation to one of the most important factors in determining the future of the race.

At the conference of child-study societies existing in various parts of the kingdom, held on May 9-II in the University of London, an address was delivered by Sir James Crichton-Browne, the presi- dent of the central society. He took for his subject the need for proper classification and education of feeble-minded children, with especial reference to the discrimination of those who presented mentally abnormal qualities not amounting to feeble-mindedness, and those whose mental defects might by suitable education under medical guidance be removed and their minds strengthened. At the meeting on May Io, papers were read by Dr. Kerr Love, on the influence of defects of hearing in relation to the mental and physical development of the child, and by $\mathrm{Mr}$. Bishop Harman, on the influence of defects of vision in relation to the mental and physical development of the child. Mr. B. P. Jones, as a teacher of the deaf, gave a successful demonstration with two ex-scholars of what may be done for the hard of hearing. Dr. Jane Walker read a paper on the tuberculous child. In the afternoon, a visit was paid to Sir Francis Campbell's normal college for the blind, where an excellent musical performance was given by members of the college. In the evening Dr. Saleeby lectured on eugenics and child-study. At the meeting on May i I, Dr. Hyslop read a paper on mental hygiene in relation to the development of the child, and a discussion ensued in which Dr. Percy Nunn and Mr. Kirkpatrick, of the Normal College, Fitchbury, Mass., took part. A discussion followed on the instruction of the young in sexual hygiene, in the course of which admirable addresses were delivered by several ladies. In the evening the delegates were entertained by Sir Richard and Lady Martin at their house in Hill Street. The next conference will be held at Liverpool.

\section{THE REFORM MOVEMENT AT CAMBRIDGE}

THE progressive party in Cambridge has lost heart about reforming the University from the inside, and a memorial asking for a Royal Commission, which has been signed by six professors and some twenty-two other members of the University, is being generally circulated for signatures. The signatories hope that power may be given to the commission to make statutes in regard to such matters as financial and other relations between the University and the colleges, and the administration of funds devoted to fellowships, scholarships, and exhibitions. A certain number of those usually associated with reform movements in the University have withheld their signatures, partly, apparently, because they mistrust the sort of commission they anticipate the present Government would nominate, and partly because they feel that the resident members have by no means made up their minds on what lines they would wish reform to be initiated; but some at least hold the view that it is not desirable that the commission should have power to frame statutes.

The petition is as follows:-

To the Right Hon. H. H. Asquith, Prime Minister.

We, the undersigned resident members of the Senate of the University of Cambridge, desire to lay before you a request that a commission may be appointed to inquire into the constitution of the University of Cambridge, the financial and other relations which exist between the University and the colleges, and the administration of funds devoted to fellowships, scholarships, and exhibitions; and that power may be given to the commission to make statutes in regard to these matters.

We venture to remind you that on July 24, 1907 , in the House of Lords, the Marquess of Crewe, speaking on behalf of the Government, stated that the

NO. 2220 , VOL. 89] 